\title{
STRATEGI GURU DALAM MENINGKATKAN KEMAMPUAN MEMBACA PESERTA DIDIK KELAS II SEKOLAH DASAR
}

\author{
Tri Yudha Setiawan
}

SD Negeri 187/VIII Bangun Seranten

Yudhasetiawan252@gmail.com

\section{INFO ARTIKEL}

Riwayat Artikel:

Diterima:01-Maret-2021

Disetujui:21-September-2021

\section{Kata Kunci:}

Strategi Kemampuan

Membaca Siswa Sekolah

Dasar

\section{ABSTRAK}

\begin{abstract}
Abstrak: Penelitian ini memiliki tujuan untuk mendeskripsikan tentang strategi guru dalam meningkatkan kemampuan membaca peserta didik. Penelitian ini merupakan penelitian kualitatif yang berisi tentang data deskripsi dari hasil wawancara mengenai startegi yang digunakan oleh guru dalam meningkatkan kemampuan membaca peserta didik. Penelitian dilaksanakan di kelas II Sekolah Dasar Negeri. Hasil penelitian menunjukan bahwa startegi guru yang digunakan untuk meningkatkan kemampuan membaca telah sesuai dengan kebutuhan peserta didik. Guru melakukan langkah-langkah pembelajaran dalam meningkatkan kemampuan membaca peserta didik yaitu: (1) Perencanaan pembelajaran terdiri dari persiapan media pembelajaran, materi pembelajaran yang dibuat kedalam RPP. (2) Pelaksanaan pembelajaran menggunakan strategi pembelajaran langsung dan startegi mandiri. (3) Evaluasi pembelajaran dilihat dari hasil tes lisan.
\end{abstract}

\begin{abstract}
This research has the goal is to describe the teacher's strategy in improving students' reading skills. This research is a qualitative research which contains descriptive data from the results of interviews regarding strategies used by teachers in improving students' reading skills. The research was conducted in grade II Public elementary school. The results showed that the teacher's strategy used to improve reading skills was in accordance with the needs of students. The teacher takes learning steps to improve the reading skills of students, namely: (1) Learning planning consists of the preparation of instructional media, learning materials that are made into RPP. (2) Implementation of learning using direct learning strategies and independent strategies. (3) The learning evaluation is seen from the results of the oral test.
\end{abstract}

\section{A. LATAR BELAKANG}

Pembelajaran merupakan proses interaksi yang dilaksanakan oleh guru dan peserta didik yang berorientasi pada tujuan yang ingin dicapai. Melalui pembelajaran peserta didik melakukan proses belajar yang berdampak pada terjadinya perubahan, perkembangan serta kemajuan dalam aspek fisik-motorik. Dampak dari proses belajar dapat dirasakan oleh peserta didik jika guru sebagai pengajar mampu mentransfer apa yang ingin disampaikan guru kepada peserta didik dengan baik. Dalam proses pembelajaran yang menjadi permasalahan yaitu bagaimana cara guru dalam memilih startegi untuk mentransfer hal tersebut.

Guru perlu menggunakan berbagai cara pengajaran karena salah satu keberhasilan peserta didik ditentukan oleh cara guru mengajar. Guru memiliki tugas dan kewajiban yang harus dilaksankan untuk mencapai tujuan. Dalam pembelajaran guru memiliki tujuan pembelajaran yang dituangkan kedalam RPP. Untuk meningkatkan hasil belajar peserta didik dapat dilakukan dengan cara memperbaiki proses pembelajaran. Cara memperbaiki proses pembelajaran yaitu dengan melakukan strategi yang tepat sesuai dengan kebutuhan. Strategi pembelajaran merupakan serangkaian atau prosedur yang dirancang oleh guru, berkaitan dengan persiapan, pelaksanaan pembelajaran untuk mendapatkan hasil belajar yang ingin dicapai (Maulana dalam Rosmala, 2018).

Strategi pembelajaran merupakan bagian terpenting dalam pembelajaran. Strategi adalah proses dalam memilih arah yang dijalani oleh suatu organisasi untuk tercapainya tujuan yang diharapkan (Faizhal Chan et al., 2019). Strategi tersebut sangat di butuhkan untuk mengatasi permasalah dalam pembelajaran. Strategi pada pembelajaran merupakan hal yang sangat dibutuhkan oleh seorang guru dalam mengatasi masalah yang terdapat didalam proses pembelajaran. Strategi tersebut diterapkan saat melakukan kegiatan mengajar. Salah satu pelajaran didalam satuan tingkat sekolah dasar yaitu Bahasa Indonesia. Bahasa Indonesia menjadi salah satu mata pelajaran yang sangat penting dikarenakan dari Bahasa tersebut mampu terjadinya komunikasi yang baik. Mata pelajaran Bahasa menjadi mata pelajaran yang berperan central bagi perkembangan serta keberhasilan peserta didik, jadi 
peningkatan kualitas perlu diupayakan melalui peningkatan keterampilan-keterampilan berbahasa (Keterampilan \& Pemahaman, 2012). Salah satu keterampilan yang harus dikuasi oleh peserta didik adalah keterampilan membaca.

Keterampilan membaca adalah keterampilan yang dimiliki oleh setiap peserta didik sesuai dengan Permendikbud No. 21 Tahun 2016 salah satu kompetensi pada pelajaran Bahasa Indonesia yaitu menyajikan secara lisan dan tulis berbagi teks sederhana yang artinya peserta didik dituntut untuk memiliki kemampuan membaca. Salah satu keterampilan yang mendapatkan informasi isi serta pemahaman dapat didapatkan melalui membaca (Pratiwi, 2020). Penelitian yang relevan dengan penelitian ini yaitu penelitian yang dilakukan oleh (Kumullah et al., 2019) dengan judul peningkatan membaca permulaan melalui media flash card pada siswa kelas rendah sekolah dasar. Dalam penelitiannya guru menggunakan media flash card untuk meningkatkan kemampuan membaca. Penelitian kedua dilakukan oleh (Dayarni, 2020) dengan judul permainan scrabbel untuk meningkatkan kemampuan membaca awal siswa kelas 1 SD N 002 belakang padang kota batam. Dalam penelitiannya guru menggunakan permainan scrabbel untuk meningkatkan kemampuan membaca peserta didik. Fokus penelitiannya yaitu pada peserta didik kelas 1. Dari kedua penelitian tersebut penelitian ini memiliki perbedaan yang terletak pada tujuan penelitian yaitu untuk mengetahui strategi yang digunakan guru dikelas II dalam meningkatkan kemampuan membaca.

Berdasarkan hasil observasi yang dilakukan oleh peneliti dikelas II, ditemukan bahwa guru telah menggunakan strategi yang sesuai dengan yang dibutuhkan oleh peserta didik. Hal tersebut ditunjukan dengan hampir seluruh peserta didik telah lancar membaca. Maka dari itu, peneliti tertarik melakukan penelitian untuk mengetahui strategi yang digunakan oleh guru dalam proses pembelajaran dengan hasil penelitian diharapkan dapat dijadikan sebagai pertimbangan bagi guru lain dalam memilih strategi untuk meningkatkan kemampuan membaca peserta didik dikelas rendah.

\section{B. METODE PENELITIAN}

Penelitian ini mengggunakan pendekatan kualitatif yang bertujuan untuk mendeskripsikan mengenai strategi guru yang digunakan untuk meningkatkan kemampuan membaca peserta didik kelas II. Tujuan dari penelitian deskriptif kualitatif yaitu untuk mendeskripsikan/menjelaskan suatu aspek yang relevan dengan fenomena yang sedang diamati (Hakim, 2020).

Teknik pengumpulan data dengan menggunakan observasi wawancara serta dokumentasi. Teknik observasi dilakukan oleh peneliti untuk melihat segala sesuatu yang terjadi selama penelitian, dari awal sampai dengan akhir. Peneliti melihat secara langsung cara guru dalam meningkatkan kemampuan membaca peserta didik didalam kelas. Teknik wawancara dalam penelitian ini menggunakan teknik wawancara tidak terstruktur. Peneliti memilih jenis wawancara tersebut karena peneliti ingin mengungkap secara mendalam bagaimana langkah-langkah atau cara yang dilakukan guru tersebut. Teknik dokumentasi dalam penelitian ini berupa pendokumentasi kegiatan pembelajaran yang dilakukan oleh guru serta RPP yang digunakan. Dalam penelitian ini uji validitas data menggunakan Triangulasi teknik.

\section{PEMBAHASAN HASIL TEMUAN}

Guru Profesional yaitu guru yang mampu menjallankan tugas sebagai pendidik, pengajar, pengarah, penilai, pelatih, pembimbing serta pengevaluasi peserta didik (Darmadi, 2015). Tugas guru pada aspek pelatih yaitu melatih peserta didik untuk mengembangkan keterampilan-keterampilan yang harus dikuasi salah satu keterampilan tersebut yaitu keterampilan membaca.

Berdasarkan hasil penelitian yang telah dilakukan, peneliti mendapatkan bahwa strategi yang digunakan oleh guru sudah terlaksana dengan tepat dan mendapatkan hasil yang baik. Dalam penerapan strategi guru memiliki beberapa langkah yaitu:

\section{Perencanaan pembelajaran}

Perencanaan pembelajaran sangat dibutuhkan untuk meningkatkan mutu pendidikan sebagai salah satu upaya yang dapat dilaksanakan (Bararah, 2017). Maka dari itu guru perlu melakukan perencanaan pembelajaran sebelum memulai proses pembelajaran dikelas. Perencanaan pembelajaran merupakan suatu keharusan yang harus dilakukan oleh seorang guru agar menyajikan pembelajaran yang terbaik untuk peserta didik.

Berdasarkan hasil wawancara yang dilakukan oleh peneliti, maka peneliti menemukan bahwa guru melakukan perencanaan pembelajaran sebelum melakukan proses pembelajaran. Strategi itu tertulis dalam rencana pelaksanaan pembelajaran yang dibuat oleh guru tersebut pada setiap pembelajaran. Guru juga menjelaskan bahwa kegiatan perencanaan yang dilakukan selalu dibuat karena perencanaan merupakan bentuk strategi untuk melakukan pembelajaran walaupun perencanaan tersebut hanya secara garis besar dari cakupan materi yang diajarkan. 


\section{Pelaksanaan Pembelajaran}

Dalam pelaksanaan pembelajaran agar terlaksana secara optimal, maka upaya yang dapat dilakukan yaitu memilih metode. pemilihan metode akan berpengaruh kepada ketercapaiannya tujuan pembelajaran (Faizal Chan, 2017). Dalam meningkatkan kemampuan membaca peserta didik, guru menggunakan strategi yang mengacu pada metode membaca basal readers kemudian dilanjutkan dengan menggunakan metode distar dan praktik metode. Metode tersebut hanyalah metode tambahan dari metode utama yaitu metode langsung dan mandiri yang digunakan oleh guru.

Dalam pelaksanaan pembelajaran terdapat beberapa faktor yang mempengaruhi kemampuan membaca peserta didik baik dari faktor dalam diri anak maupun faktor luar. Faktor tersebut seperti kondisi fisik peserta didik, kesiapan peserta didik, lingkungan peserta didik, dan cara orang tua mendidik peserta didik dirumah. Pada faktor lingkungan peserta didik tidak akan mengalami kendala yang berarti dalam hal membaca jika peserta didik tumbuh serta berkembang di dalam keluarga yang harmonis, keluarga dengan penuh cinta kasih dan memahami anaknya sendiri (Partikasari et al, 2014).

\section{Evaluasi}

Evaluasi dalam pembelajaran yang dilakukan dengan melihat kemajuan yang dicapai oleh peserta didik melalui tes lisan. Evaluasi juga memberikan gambaran untuk guru melakukan tindakan selanjutnya apakah ada kekurangan yang harus diperbaiki dalam proses pembelajaran baik dari segi guru ataupun peserta didik.

\section{SIMPULAN DAN SARAN}

Berdasarkan hasil penelitian yang dilakukan oleh peneliti dikelas II mengenai strategi guru dalam meningkatkan kemampuan membaca peserta didik maka diperoleh bahwa guru menggunakan beberapa tahapan yaitu merencanakan, pelaksanaan serta evaluasi dalam proses pembelajaran. Dalam pelaksanaan guru menggunakan strategi pembelajaran langsung serta strategi mandiri.

Penelitian ini adalah penelitian awal yang hanya mendeskripsikan strategi untuk meningkatkan kemampuan membaca. Penulis mengharapkan bagi peneliti selanjutnya untuk mengupas tuntas strategi dan pelaksanaan dilihat dari dampak serta kekurangan penggunaan. Penelitian ini bisa dijadikan sebagai referensi pendukung untuk penelitian selanjutnya.

\section{DAFTAR RUJUKAN}

[1] Bararah, I. 2017. Efektifitas Perencanaan Pembelajaran dalam Pembelajaran Pendidikan Agama Islam di Sekolah. Jurnal MUDARRISUNA: Media Kajian Pendidikan Agama Islam, 7(1), 131-147.

[2] Chan, Faizal. 2017. Implementasi Guru Menggunakan Metode Permainan Pada Pelajaran IPA Di Sekolah Dasar. Jurnal Gentala Pendidikan Dasar, 2(1), 106-123. https://doi.org/10.22437/gentala.v2i1.6821

[3] Chan, Faizhal, Kurniawan, A. R., . N., Herawati, N., Efendi, R. N., \& Mulyani, J. S. 2019. Strategi Guru Dalam Mengelola Kelas di Sekolah Dasar. International Journal of Elementary Education, 3(4), 439. https://doi.org/10.23887/ijee.v3i4.21749

[4] Darmadi, H. 2015. MENJADI GURU PROFESIONAL diperbincangkan, karena guru merupakan sumber kunci keberhasilan pendidikan . didik yang menyangkut berbagai aspek yang bersifat manusiawi yang unik dalam. Jurnal Edukasi, 13(2), 161-174.

[5] Dayarni, D. 2020. Permainan Scrabble untuk Meningkatkan Kemampuan Membaca Awal Siswa Kelas 1 SDN 002 Belakang Padang Kota Batam. Lectura: Jurnal Pendidikan, 11(2), 270-281. https://doi.org/10.31849/lectura.v11i2.4753

[6] Hakim, P. R. 2020. UPAYA MENINGKATKAN KETERAMPILAN MEMBACA PERMULAAN PADA ANAK USIA DINI MELALUI MEDIA KARTU KATA BERGAMBAR. 1(1), 51-61.

[7] Keterampilan, P., \& Pemahaman, M. 2012. Peningkatan Keterampilan Membaca Pemahaman Melalui Strategi Know-Want-Learned (Kwl) Pada Siswa Kelas Iva Sdn Sekaran 01 Semarang. Joyful Learning Journal, 1(1), 62-70. https://doi.org/10.15294/jlj.v1i1.2147

[8] Kumullah, R., Yulianto, A., \& Ida, I. 2019. Peningkatan Membaca Permulaan Melalui Media Flash Card pada Siswa Kelas Rendah Sekolah Dasar. Jurnal Pendidikan, 7(2), 36-42. https://doi.org/10.36232/pendidikan.v7i2.301

[9] Partikasari, R., Suryani, N. A., \& Imran, R. F. 2014. Peningkatan Kemampuan Membaca Permulaan Dengan Menggunakan Metode Bermainflash Card Subaca Di Paud Al- Anisa Bentiring Kota Bengkulu. Jurnal Ilmiah Potensia, 3(4), 1-19.

[10] Pratiwi, C. P. 2020. Analisis Keterampilan Membaca Permulaan Siswa Sekolah Dasar. Jurnal Pendidikan 
Edutama, 7(1), 1-8.

Setiawan Tri Yudha. (2021).

Jurnal Pendidikan Dasar Flobamorata. Vol. 2 (2) hal. 176-179. 